\title{
Skeletal structures and habitats of Recent and fossil Acanthochaetetes (subclass Tetractinomorpha, Demospongiae, Porifera)
}

\author{
J. Reitner ${ }^{1}$ and T.S. Engeser ${ }^{2}$ \\ ${ }^{1}$ Institut für Paläontologie der Freien Universität Berlin, Schwedenerstrasse 8, D-1000 Berlin 33 \\ ${ }^{2}$ Geologisch-Paläontologisches Institut und Museum der Universität Hamburg, \\ Bundesstrasse 55, D-2000 Hamburg 13, Federal Republic of Germany
}

Accepted 12 November 1986

Abstract. The investigation of the habitats, the spicular skeletons, and the structure and chemistry of the nonspicular high-Mg calcite skeletons of a fossil Acanthochaetetes from the Late Albian (Cretaceous) of Northern Spain and the extant Acanthochaetetes wellsi from Pacific reefs demonstrates an astonishing correspondence. The skeletons of both species are hemispherical or pyriform with the lower part containing an epitheca. They are built up of single calicles which are subdivided by tabulae. Spines protrude from the walls into the calicles. Scanning electron microscopy and thin sections reveal that the high$\mathrm{Mg}$ calcite skeleton consists of two different microstructures: a irregular (sensu Wendt 1979) or microlamellar (sensu Cuif et al. 1979) and a completely irregular structure. AAS and EDAX analysis of the calcite skeletons produce roughly the same $\mathrm{Mg}$ and $\mathrm{Sr}$ contents. Tylostyle megascleres and aster-like microscleres are observed in the spicular skeletons of both species. The only difference between the two species is the greater variability of the microscleres in the extant species. Moreover, the fossil species incorporates the scleres in the non-spicular skeleton, while the extant species does not. Both species live/lived in the same niches of tropical reefs: the cryptic habitats of submarine caves in the reef core and the dimly lighted habitats of the deeper fore-reef.

\section{Introduction}

The acanthochaetetids are tabulate "sclerosponges" which possess both a non-spicular, high-Mg calcite skeleton and a spicular skeleton of siliceous mega- and microscleres. The relationship of the only (?three) living species (Hartman and Goreau 1975; Mori 1976, 1977) has been questioned (Mori 1976, 1977; Fischer 1977) principally because previously described fossil specimens lack the spicular skeleton.

The spicular skeleton of Acanthochaetetes shows strong similarities with the genus Spirastrella, order Hadrome-
rida(Van Soest 1984; Vacelet 1985; Engeser et al. 1986). In cladistic terms, the Acanthochaetetidae and the Spirasterellidae are sister-groups and the calcareous skeleton may be interpreted as an apomorphic feature. However, it cannot be fully excluded that Spirastrella lost the basal calcareous skeleton and loss of the calcareous skeleton is therefore the apomorphic character.

We compared a fossil species - Acanthochaetetes seunesi (Fischer 1970) - from the Late Albian (Cretaceous) of northern Spain with the hard parts of the extant species - Acanthochaetetes wellsi Hartman and Goreau 1975 from Pacific reefs using different examination methods (thin sections, SEM, AAS, EDAX). The comparison revealed that a separation at a higher systematic rank (new genus and new family for the Recent species) or even exclusion of the fossil species from the phylum Porifera as done by Mori $(1976,1977)$ and Fischer $(1970,1977)$ is unjustified. In fact, the two species show a large degree of correspondence in habitats, spicular skeletons, and the structure and chemistry of the non-spicular skeletons.

\section{Material and methods}

Through the courtesy of Prof. J. Wendt (Tübingen), we were able to examine two specimens of the Recent Acanthochaetetes wellsi Hartmann and Goreau (1975) from Guam (Mariana Islands, Pacific) as well as one specimen from the Great Barrier Reef (Australia). One specimen from Guam was dried and the other specimen was treated with 5\% hypochlorite solution to remove the soft tissue. The fossil specimens of Acanthochaetetes seunesi (Fischer 1970) were collected in the Late Albian fore-reef marls approximately one kilométer north of the small village of Araya (prov. Álava, Northern Spain) (for more detailed section information see Reitner 1982, 1985).

For this study we utilized only the best preserved fossil specimens (approx. 10), from which more than 50 thin sections were made. The thin sections were examined with the light microscope under high magnifications (up to $200 \times$ ). To expose the spicules, roughly polished sections were etched with $5 \%$ titriplex-III-solution ${ }^{1}$. After about 2 days of treatment in the titriplex-III-solution, the samples were thoroughly cleaned with distilled water and then dried. Subsequently the etched surface was examined with the Scanning electron microscope. 
SEM studies were also undertaken on freshly fractured surfaces of both the fossil and Recent material, to compare the microstructures of the calcitic skeletons. The SEM studies were carried out with goldpalladium as well as carbon-coated material. The chemical analyses of the calcitic skeletons were performed with Atomic absorption spectroscopy (AAS) and Energy dispersive X-ray analysis (EDAX)

\section{Demosponges with a secondary calcareous skeleton}

Secondary calcareous skeletons occur within different subclasses of the demosponges. These so-called "sclerosponges" or "coralline sponges" are certainly polyphyletic (Vacelet 1985; Reitner, in press). The modern representatives of these calcareous demosponges can be distinguished, apart from differences in the soft part anatomy, by different types of mineralogy and microstructures. The first group has an aragonitic skeleton with either a clinogonal microstructure (Ceratoporella), or a spherulitic microstructure (Astrosclera, Calcifibrospongia) or a totally irregular arrangement of the aragonite crystals (Vaceletia). The second group has a high-Mg calcite skeleton either with a clinogonal microstructure (Merlia) or a irregular/microlamellar microstructure (Acanthochaetetes) (Wendt 1979; Cuif et al. 1979). The irregular/microlamellar microstructure is restricted to the genus Acanthochaetetes which appeared in the fossil record in the Late Jurassic. This diagnostic character in combination with extremely high Mg-values of about $19.9 \mathrm{~mol}-\%$ is not observed yet anywhere in the phylum Porifera.
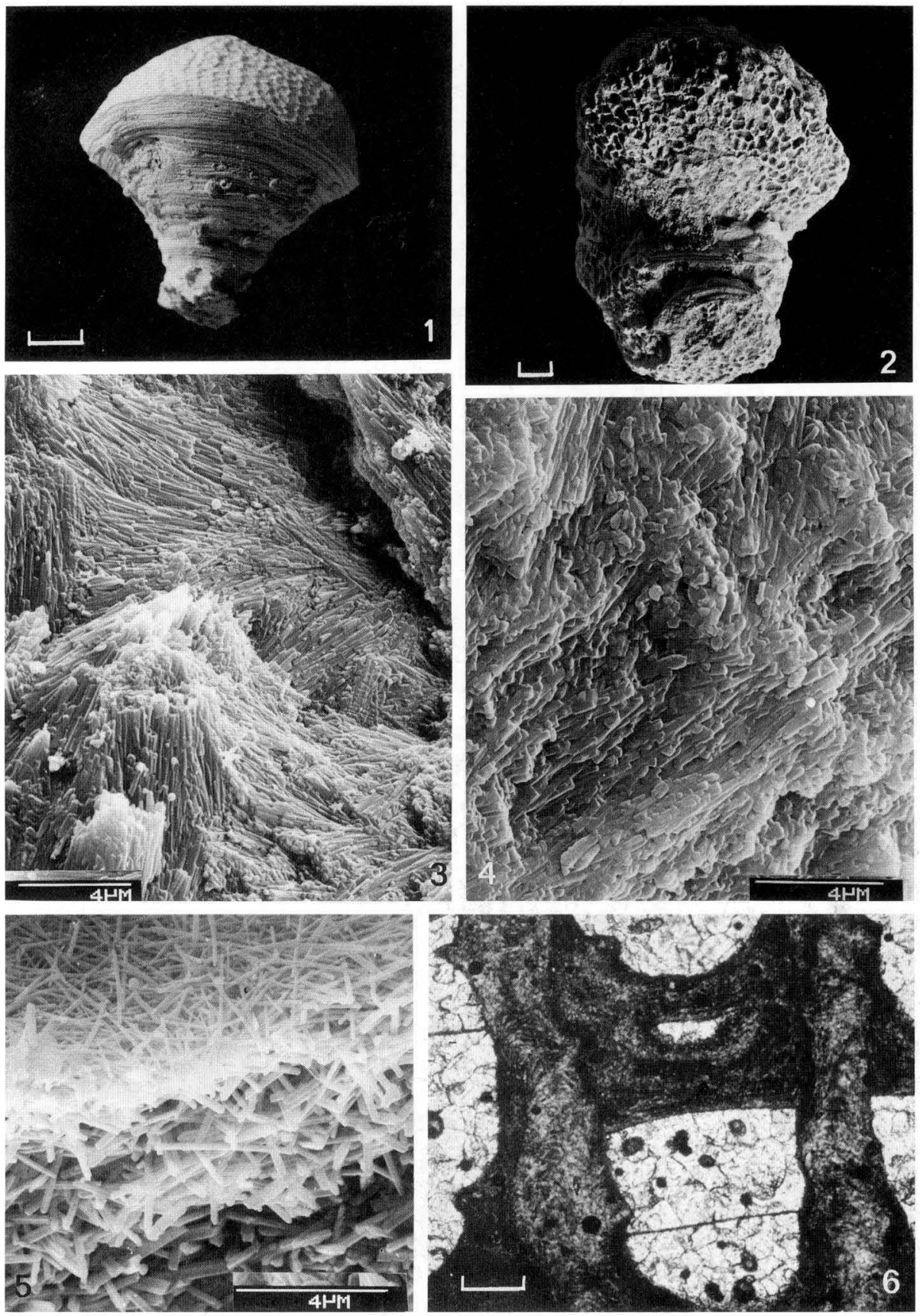

Fig. 1. Acanthochaetetes wellsi (Hartman and Goreau 1975). Great Barrier Reef (Australia), outline in lateral view. The epitheca with concentric growth lines covers the lower surface of the sponge (GPIT no. 1613/1, GPIT Collection of Geologisches-Paläontologisches Institut der Universität Tübingen, FRG). Scale $=2 \mathrm{~cm}$

Fig. 2. Acanthochaetetes seunesi (Fischer 1970) Late Albian of northern Spain, top view. The skeleton is built up by vertical calicles or tubes which have an elliptical cross section (GPIT no. 1613/2). Scale $=2 \mathrm{~mm}$

Fig. 3. Acanthochaetetes wellsi, microstructure of the high-Mg calcite skeleton, primary central wall structure with high-Mg calcite crystals bundles, SEM photo

Fig. 4. Acanthochaetetes seunesi, microstructure of the high- $\mathrm{Mg}$ calcite skeleton, primary central wall structure with high-Mg calcite crystals bundles, SEM photo

Fig. 5. Acanthochaetetes wellsi, microstructure of the high-Mg calcite skeleton, secondary structure of the tabulae and of the coatings of the tubes, randomly orientated single crystals of high-Mg clacite, SEM photo

Fig. 6. Acanthochaetetes seunesi, microstructure of the high- $\mathrm{Mg}$ calcite skeleton, secondary wall structure of the tabulae and coatings of the tubes, thoroughly micritized high-Mg calcite of formerly single crystals of high-Mg calcite, thin section (GPIT no. 1613/3).

Scale $=0.2 \mathrm{~mm}$ 


\section{Morphology and structure of the non-spicular skeleton}

The skeleton of Acanthochaetetes wellsi is hemispherical to pyriforme (Fig. 1). A well developed epitheca containing concentric growth lines covers the lower half of the surface of the sponge (Fig. 1). The exact growth is dependent on the habitat. The same appears to be true of the fossil Acanthochaetetes seunesi (Fig. 2). Recent Acanthochaetetes can reach $35 \mathrm{~cm}$ in diameter (Hartman and Goreau 1975), the fossil species approx. $15 \mathrm{~cm}$. The calcareous skeletons of Recent specimens possess radiating depressions that record the position of the exhalant channels (astrorhizae) which are rarely situated on mamelon structures. In the fossil specimens, these evidence of exhalant channels are also present, but mamelon structures are lacking. In many Recent "sclerosponges" mamelon structures may be present or not within the same species (Hartman 1984). The calcitic nonspicular skeleton of Acanthochaetetes wellsi is composed of vertical calicles and consists of high-Mg calcite. Most of the calicles or tubes are elliptical in cross section and distance between their centres ranges from $0.35 \mathrm{~mm}$ to $0.6 \mathrm{~mm}$ (for more detailed description see Hartman and Goreau 1975). The internal morphology of the fossil sponge species is identical to that of the extant sponge. The distance between the tube centres ranges from $0.4 \mathrm{~mm}$ to $0.8 \mathrm{~mm}$ in our material, but can be highly variable within the same specimen.

The calcitic skeleton of both species is composed of two different arrangements of the high- $\mathrm{Mg}$ calcite crystals. The primary wall structure consists of irregular (sensu Wendt 1979, "microlamellaire" sensu Cuif et al. 1979) arranged high-Mg calcite crystals bundles (Figs. 3 and 4). In contrast, the secondary wall structure of the tabulae and of the coating of the tubes shows randomly orientated single crystals of high-Mg calcite (Fig. 5). This second type of microstructure is formed passively without any direct influence of the soft tissue and can be explained as a special cement formed during the very early diagenesis of the ontogenetic older parts of the calcareous skeleton (Reitner in press). These differences can be distinguished in thin sections (Figs. 5 and 6). In the fossil specimens the randomly orientated layer is thoroughly
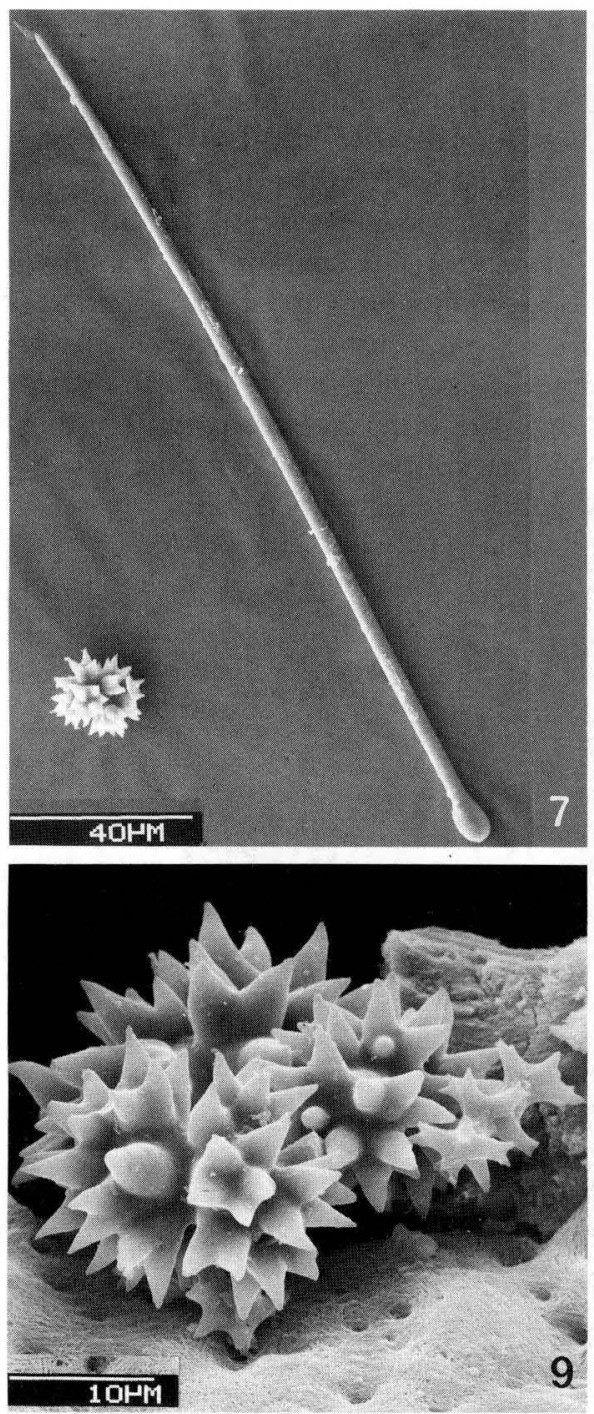
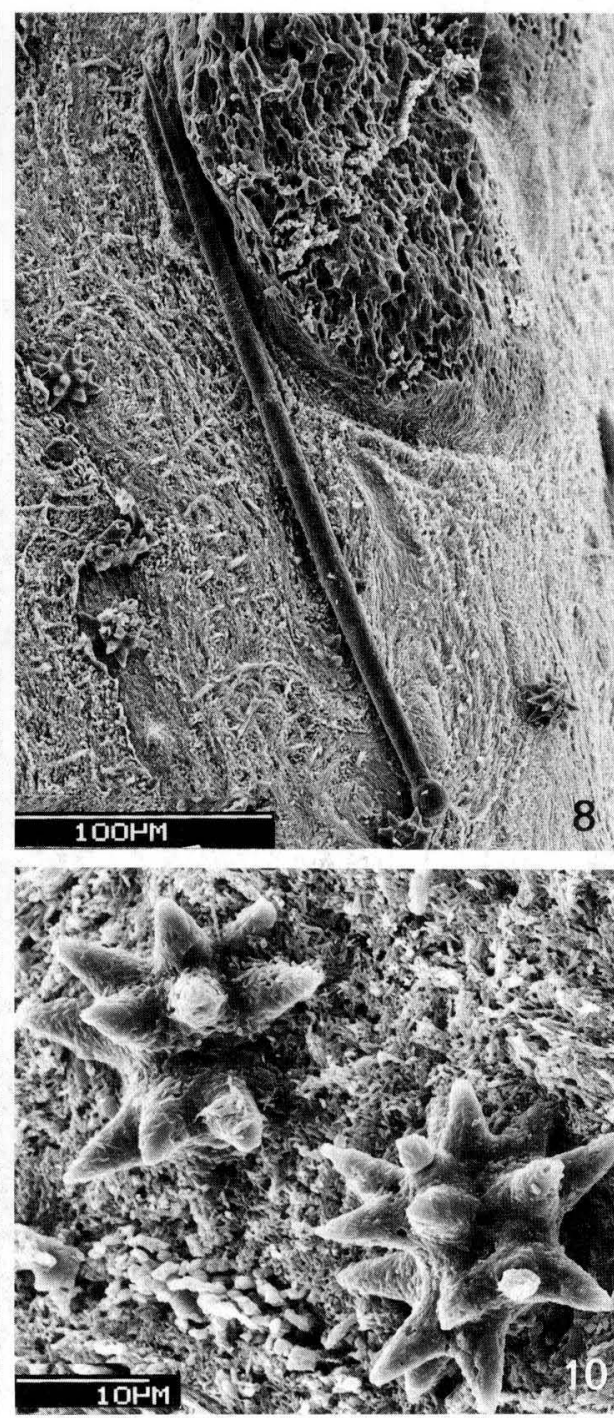

Fig. 7. Acanthochaetetes wellsi, spicular skeleton, slender tylostyle megasclere SEM photo

Fig. 8. Acanthochaetetes seunesi, spicular skeleton, considerable thicker tylostyle megasclere, SEM photo

Fig. 9. Acanthochaetetes wellsi, spicular skeleton, spiraster microscleres, SEM photo

Fig. 10. Acanthochaetetes seunesi, spicular skeleton, spiraster microscleres, SEM photo 
micritized and is darker than the irregular/microlamellar high-Mg calcite crystals bundles of the primary wall structure, which is formed by the organic tissue of the sponge (Fig. 8).

\section{Chemistry of the non-spicular skeleton}

The main element content ( $\mathrm{Ca}$ and $\mathrm{Mg}$ ) was analysed with AAS and EDAX (Figs. 13, 14). The high-Mg calcite of the Recent Acanthochaetetes wellsi contains $19.9 \mathrm{~mol} \% \mathrm{Mg}$ (Wendt 1979), in fossil specimens up to $5.0 \mathrm{~mol}-\% \mathrm{Mg}$ (Fig. 11) were measured. The corresponding remaining mol- $\%$ are $\mathrm{Ca}$ and trace elements (less than $1 \mathrm{~mol}-\%$ ). Diagenetic changes must be taken into account when comparing fossil and extant sponge species. The tubes or calicles of the high-Mg calcite skeleton of the fossil species are filled with a diagenetic Fe-rich low-Mg calcite. Since the high- $\mathrm{Mg}$ calcite skeleton and the tube-filling diagenetic low-Mg calcite can hardly separated, the AAS-analysis results always show a reduction in the $\mathrm{Mg}$ content. Increasing diagenetic alteration of the skeleton can result in the mobilisation of $\mathrm{Mg}$ which further decreases the $\mathrm{Mg}$ content. This can lead to complete elimination of $\mathrm{Mg}$ from an original high-Mg calcite skeleton. In our material, the EDAX Mg-peaks of the Recent and the fossil species show no significant differences as long as the analysis point is located at the centers of the calicle walls of the fossil specimens (Figs. 13,14). When the analysis point was located on the tube-filling composed of diagenetic low-Mg calcite, no $\mathrm{Mg}$ peak was observed. We assume therefore, that the apparent low-Mg content indicated by the AAS analysis can be explained as contamination of the high-Mg skeletal calcite by low-Mg diagenetic material. Decreased $\mathrm{Mg}$ contents due to diagenetic alteration can probably be excluded.

Proof of slight diagenetic alternation is also found in the trace elements $\mathrm{Sr}$ and $\mathrm{Mn}$ determined by AAS. The EDAX analysis gives no significant peaks, since the original contents are too low. Recent skeletal high-Mg calcite contains approx. $2000 \mathrm{ppm}$ to $3000 \mathrm{ppm} \mathrm{Sr}$ (Veizer and Wendt 1976). The analysis of the high-Mg calcite skeleton (including the tube-filling diagenetic low-Mg calcite) of the fossil analogue yielded up to $1300 \mathrm{ppm} \mathrm{Sr}$ (mean $1100 \mathrm{ppm} \mathrm{Sr}$ ). Diagenetic low-Mg calcite of the surrounding reefal limestones in the Albian of Northern Spain reaches $110 \mathrm{ppm}$ Sr to $970 \mathrm{ppm} \mathrm{Sr}$ (mean $230 \mathrm{ppm}$ Sr) (Fig. 11). On the other hand, increasing diagenesis results in an increase of the Mn-content (Veizer and Wendt 1976). In our material, the Mn content is very low (Fig. 12). These results suggest that the high-Mg calcite skeletons of the fossil Acanthochaetetes seunesi are very little altered diagenetically and that they contained originally the same proportion of $\mathrm{Mn}$ and $\mathrm{Sr}$ as the Recent ones.

\section{Spicular skeletons}

In Acanthochaetes wellsi, the soft tissue covers only the uppermost parts of the calicles (approx. 2 to $3 \mathrm{~mm}$;
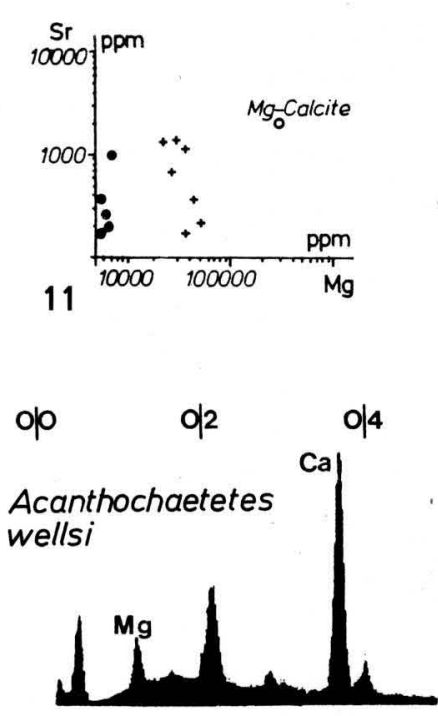

13

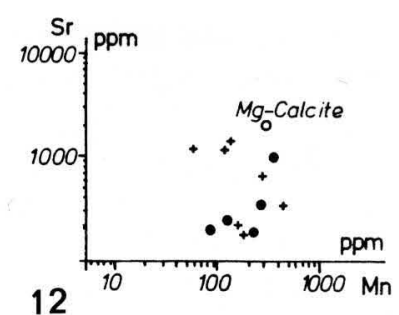

op

이 2

이 4

Acanthochaetetes seunesi

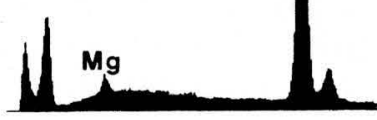

14
Fig. 11. AAS-analysis, diagram $\mathrm{Mg}$ versus $\mathrm{Sr} .+=$ analysis of Acanthochaetes seunesi, Late Albian of northern Spain; $O=$ analysis of diagnostic altered reef limestones, Late Albian reefs of northern Spain

Fig. 12. AAS-analysis, diagram $\mathrm{Mn}$ versus $\mathrm{Sr} .+=$ analysis of Acanthochaetes seunesi, Late Albian of northern Spain; O = analysis of diagnostic altered reef limestones, Late Albian reefs of northern Spain

Fig. 13. Acanthochaetetes wellsi, EDAX-analysis

Fig. 14. Acanthochaetetes wellsi, EDAX-analysis. The difference in the height of the Mg peaks between Acanthochaetetes wellsi and Acanthochaetetes seunesi is comparably slight. The analysis point was located on the center of the wall structure

Hartman and Goreau 1975) and also contains the spicular skeleton. Differences in spicular skeletons distinguish the three Recent Acanthochaetetes-species described (Hartman and Goreau 1975; Mori 1976, 1977), the calcareous skeletons of all three Recent species are identical. However, two species, Acanthochaetetes japonica (Mori 1977), and Acanthochaetetes horiguchii (Mori 1976) are highly dubious. Fusiform megascleres (A. horiguchii) or dichotriaene megascleres $(A$. japonica) are unknown within the hadromerid demosponges that show tylostyle or subtylostyle megascleres only. All known fossil Acanthochaetetes-species as well as Acanthochaetetes wellsi exhibit tylostyle megascleres and variable spiraster microscleres (Hartman and Goreau 1975; Reitner and Engeser 1983; Vacelet, in press).

We suppose a contamination of Mori's material with scleres of another sponge. We have different reasons for this assumption. First, Mori's specimens were collected after being washed ashore and were not found in situ. Secondly, the two species are only known from the holotypes. There are no other specimens of these species, whereas up to now thousands of specimens of Acanthochaetetes wellsi are collected. Moreover, we observed the same phenomenon in material not used for this study. A calcareous skeleton from the Philippines and indistinguishable from the calcareous skeleton of Acanthochaetetes wellsi, was encrusted by a hexactinellid sponge. In this 
case, we are sure that soft parts and calcareous skeleton do not belong together, a statement, which is, however, not so obvious in Mori's case. The dichotriaene megascleres of "A.japonica" are characteristic for the order Choristida, whereas the fusiform megascleres and aster-like microscleres of the second species ("A. horiguchii") indicate to another family of the tetractinomorph demosponges. However, before a detailed reinvestigation of Mori's material we won't exclude the possibility that a second group of tetractinomorph demosponges also developed an Acanthochaetetes-like calcareous skeleton. Only the scler types and the scler arangement can be used for systematic classification. The calcareous skeleton is, as demonstrated above, a highly polyphyletic character.

The spicular skeleton of Acanthochaetetes wellsi consists of siliceous megascleres and microscleres, which are composed of amorphous silica. The megascleres are slender tylostyles (Fig. 7), varying from $201 \mu \mathrm{m}$ to $336 \mu \mathrm{m}$ (mean $286 \mu \mathrm{m}$ ) in length (Hartman and Goreau 1975). The microscleres are basically spirasters, but highly variable in form (Fig. 9). The greatest length versus greatest width ranges from $28 \mu \mathrm{m}$ versus $20 \mu \mathrm{m}$ to $6 \mu \mathrm{m}$ versus $5 \mu \mathrm{m}$ (Hartman and Goreau 1975).

The fossil Acanthochaetetes seunesi also has tylostyle megascleres (Fig. 8), but they are considerably thicker. The length ranges from approx. $200 \mu \mathrm{m}$ to $350 \mu \mathrm{m}$. The microscleres are basically spirasters (Fig. 10). Their diameters range from approx. $10 \mu \mathrm{m}$ to $30 \mu \mathrm{m}$. These slight differences justify a specific separation on the species level (for systematic consequences see Reitner and Engeser 1983; Engeser et al. 1987). In our material of Acanthochaetetes, most of the originally siliceous spicules have been transformed into single crystals of a Fe-rich low-Mg calcite so that an isolation of the spicules could not be achieved. However, after treatment with titriplex-
III-solution the spicules remained stable for a short time on the etched surface of the sponge before complete dissolution. When cleaned in this stage, the scleres could be examined with the SEM.

The incorporation of the megascleres of Acanthochaetetes seunesi in the rigid calcareous skeleton is usually rare and appears to be accidentical, whereas the incorporation of the microscleres is more frequent. Both may be caused by the calcification process. This process, which might have been similar to that observed in some calcareous green algae, involves the precipitation of calcite in a mucus layer between the skeleton and the soft tissue. This process normally hinders the incorporation of spicules into the calcareous skeleton. We observed an enrichment of scleres within the calcareous skeleton in parts of growth interruptions and inclusions of extraneous material. During growth interruptions the soft tissue of the sponge decayed, but the spicules remained on the surface of the calcareous skeleton. A new growth of the sponge, caused by the "storage-cells" within the calcareous skeleton (Vacelet, in press), resulted in the incorporation of the older scleres and further extraneous material in the calcitic skeleton. Under such conditions, the scleres can be more frequent within the calcareous skeleton.

There are, however, still undescribed fossil Acanthochaetetes-species from the Early Cretaceous of northern Spain which regularly incorporate the scleres, while other fossil species do not. An incorporation of scleres in the extant Acanthochaetetes wellsi was not observed, even in areas with inclusions of extraneous materials. The reason for incorporation or nonincorporation of scleres in various Acanthochaetetes species, as well as the systematic value of this character is unknown.

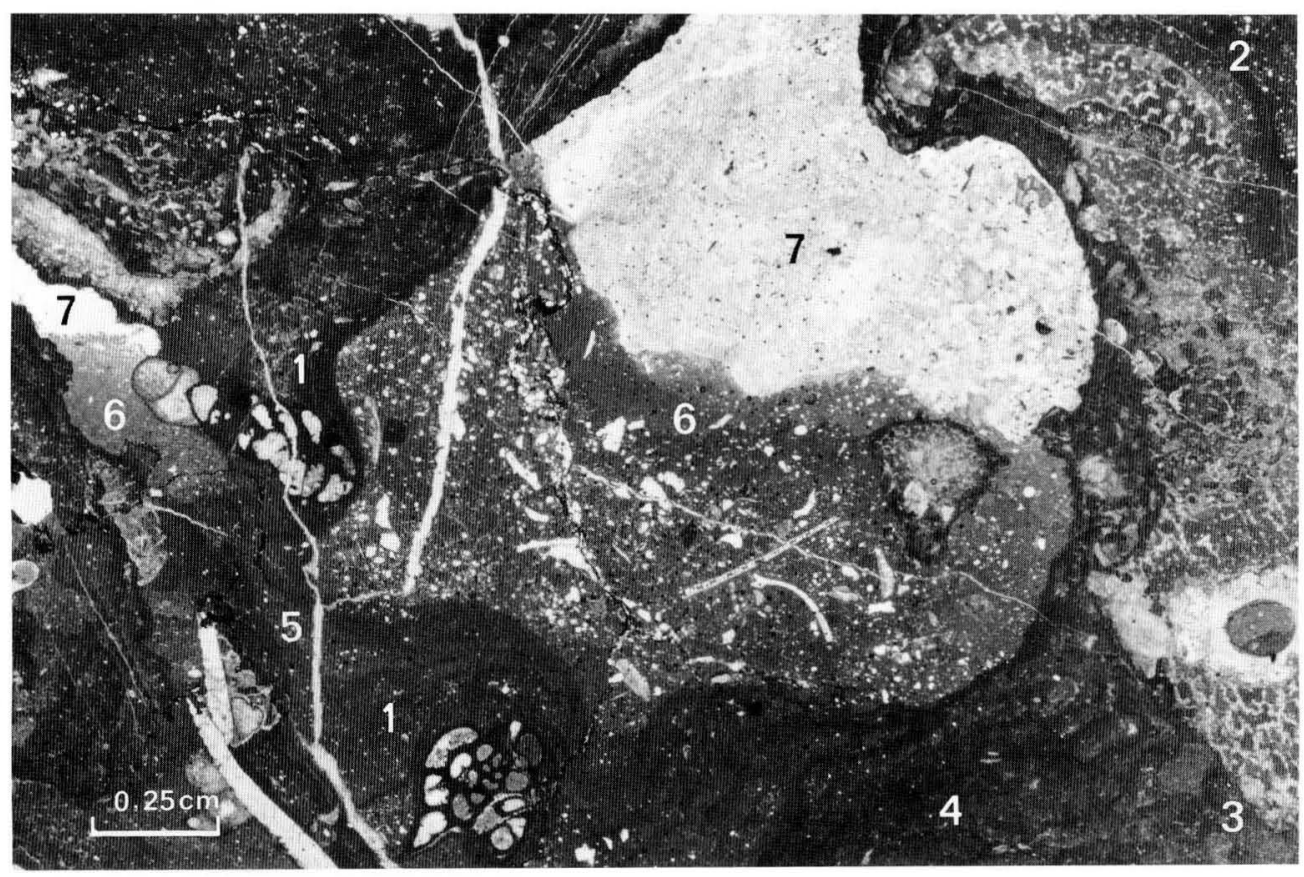

Fig. 15. Acanthochaetetes-community of a fore-reef mound of a MidCretaceous reef platform of northern Spain.

$1=$ Acanthochaetetes $\mathrm{sp}$; 2 = lithistid sponge; $3=$ stromatoporoid sponge; $4=$ blue green algae-crusts; $5=$ Placopsilina $s p$. (crustose foraminifera); $6=$ primary vug filled with sediment; $7=$ remaining pore space of the primary vug filled with a late diagenetic blocky calcite 


\section{Habitats}

Living Acanthochaetetes wellsi occur in cryptic habitats such as submarine caves of the reef core associated with brachiopods, red algae, crustose foraminifera, serpulids, and bryozoans (Basile et al. 1984) and in the dim light of the deep fore-reef(Hartman and Goreau 1975; Basile et al. 1984). In Late Albian reefs, specimens of Acanthochaetetes seunesi are found in the interfingering areas of the reefs with basin marls together with a lithistid, hexactinellid, "sphinctozoan" sponge community (Reitner and Engeser 1983). They are also observed in small cave fillings [associated with small brachiopods and crustose foraminifera (Reitner and Engeser 1983; Reitner 1985)], in the fillings of larger borings, and underneath large mushroom-like corals in the central reef core (Fig. 15). From these occurrences one can presume that the Late Albian Acanthochaetetes seunesi also seemed to prefer dim light or cryptic habitats. In Late Albian/Early Cenomanian times, however, an Acanthochaetetes group existed, which also occupied photic niches in shallow marine reef habitats (Reitner and Engeser 1983; Reitner 1985). This group became extinct during the Cenomanian.

The Acanthochaetetes-communities in Late Albian and present reefs are very similar, because only few organism groups of this aphotic faunal association changed their habitat (e.g., some lithistid sponges) or died out (e.g., most "sphinctozoan" sponges). The extant species is known from tropical reefs in the Pacific (Hartman and Goreau 1975; Mori 1976, 1977; Basile et al. 1984). The fossil species is reported from Albian and Cenomanian reefs of Central France (Fischer 1970, 1977), the Pyrenees (Fischer 1970, 1977) and the north Spanish Vasco-Cantabrian Basin (Reitner 1982, 1985; Reitner and Engeser 1983). The main reef building organisms indicate that these Late Albian reefs of Northern Spain were typical tropical reefs (Reitner 1982, 1985). This may indicate a more southward position of the Iberian Plate and/or a more northward occurrence of tropical reefs during the Mid-Cretaceous.

\section{Discussion}

We agree with Vacelet $(1981,1985)$ that the class Sclerospongia (Hartmann and Goreau 1975) is polyphyletic and should be eliminated. He emphazised corresponding spicular skeletons and soft tissue. We have established the Acanthochaetetidae as the sister-group of the Spirastrellidae (order Hadromerida) and the order Tabulospongida (Hartman and Goreau 1975) should therefore be eliminated too (Engeser et al., in press). The family Acanthochaetetidae (Fischer 1970) is transferred into the order Hadromerida.

An extant species, which shows a very close correspondence in morphology to an extinct one, is called a "living fossil". Acanthochaetetes wellsi does exhibit these typical attributes (Vacelet 1983). There are no significant differences in internal and external morphology, chemis- try and microstructure of the high-Mg calcite skeleton or habitat between the fossil Acanthochaetetes seunesi of the Late Albian reefs of northern Spain and the Recent Acanthochaetetes wellsi. The genus Acanthochaetetes survived in a very restricted ecological niche of a reef: the cryptic habitats of the submarine caves of the reef core and the dim light habitats of the deep fore-reef (Basile et al. 1984). Not only has Acanthochaetetes survived, but also the Acanthochaetetes faunal community has remained almost unchanged.

\section{References}

Basile LL, Cuffey RJ, Kosich DF (1984) Sclerosponges, Pharetronids and Sphinctozoans (relict cryptic hard-bodied Porifera) in the modern Reefs of Enewetak Atoll. J Paleontol 58:636-650

Cuif J-P, Debrenne F, Lafuste JG, Vacelet J (1979) Comparaison de la microstructure du squelette carbonaté non spiculaire d'éponges actuelles et fossiles. Coll Int CNRS 291:459-465

Engeser TS, Floquet M, Reitner J (1987) Acanthochaetetidae (Hadromerida, Demospongiae) from the Coniacian of Vera de Bidasoa (Basque Pyrénées, Northern Spain). Geobios 19:849-854

Fischer J-C (1970) Révision et essai de classification des Chaetetida (Cnidaria) post-paleozoïques. Ann Paléontol (Invert) 56:151-220

Fischer J-C (1977) Biogéographie des Chaetetida et des Tabulospongida post-paleozoïques. Mém BRGM 89:530-534

Hartman WD (1984) Astrorhizae, mamelons and symbionts of Recent sclerosponges. Palaeontogr Am 54:305-314

Hartman WD, Goreau TF (1975) A Pacific tabulate sponge, living representative of a new order of sclerosponges. Postilla 167:1-21

Mori K (1976) A new sclerosponge from Ngargol, Palau Island and its fossil relatives. Tohoku Univ Sci Rep 2 Ser Geol 46:1-9

Mori K (1977) A calcitic sclerosponge from the Ishigaki-shima coast, Ryukyu Islands, Japan. Tohoku Univ Sci Rep 2 Ser Geol 47:1-5

Reitner J (1982) Die Entwicklung von Inselplattformen und DiapirAtollen im Alb des Basko-Kantabrikums (Nordspanien). N Jahrb Geol Paläontol Abh 165:87-101

Reitner J (1985) Mikrofazielle, palökologische und paläogeographische Analyse ausgewählter Vorkommen flachmariner Karbonate im Basko-Kantabrischen Strike Slip Fault-Becken-System (Nordspanien) an der Wende von der Unterkreide zur Oberkreide. $\mathrm{PhD}$ thesis, Universität Tübingen

Reitner J (in press) The polyphyletic origin of the "sphinctozoans". In: Proceedings of the Third International Conference of Sponge Biology. Smithsonian Institution Press, Washington, DC

Reitner J, Engeser TS (1983) Contributions to the systematics and the paleoecology of the family Acanthochaetetidae (Fischer 1970) Order Tabulospongida, Class Sclerospongiae). Geobios 16:773-779

Vacelet J (1981) Éponges hypercalcifiées ("Pharétronides", "Sclérosponges") des cavités des récifs coralliens de Nouvelle-Calédonie. Bull Mus Nat Hist Paris 3 (Sér 4, Sec A, Nr. 2):313-351

Vacelet J (1983) Les éponges calcifiées et les récifs anciens. Pour la Science 68:14-22

Vacelet J (1985) Coralline sponges and the evolution of Porifera. In: Conway Morris S, George JD, Gibson R, Platt HM (eds) The origins and relationships of lower invertebrates. Syst Assoc Spec 28:1-13

Vacelet $\mathrm{J}$ (in press) The storage cells of calcified relict sponges. In: Proceedings Third International Conference of Sponge Biology. Smithsonian Institution Press, Washington, DC

Van Soest R (1984) Deficient Merlia normani Kirkpatrick, 1908, from the Curaçao reefs, with a discussion on the phylogenetic interpretation of sclerosponges. Bijdr Dierkd 54:211-219

Veizer J, Wendt J (1976) Mineralogy and chemical composition of Recent and fossil skeletons of calcareous sponges. N Jahrb Geol Paläontol Mh 1976:558-573

Wendt J (1979) Development of skeletal formation, microstructure, and mineralogy of rigid calcareous sponges from the late Palaeozoic to Recent. Coll Int CNRS 291:449-457 